\title{
Long-term results of pulmonary autograft for aortic valve replacement
}

\author{
JANE SOMERVILLE, OSCAR SARAVALLI, ${ }^{1}$ DONALD ROSS, \\ AND SUSAN STONE ${ }^{2}$ \\ From the National Heart Hospital, Westmoreland Street, London
}

SUMMARY Eighty-five survivors who left hospital after pulmonary autograft replacement for severe aortic regurgitation have been followed critically. Five patients died in the first five years and 80 were followed for six to 11 years. Important aortic regurgitation occurred only early and was always related to technical malpositioning of one autograft cusp. Seven patients with fascial pulmonary valves had problems, requiring removal in four. There was a small (2\%) morbidity from the right sided homograft and six were removed five to seven years later for progressive calcification; three of these had been irradiated. Despite a high incidence of trivial diastolic murmurs this valve replacement is still preferred for young patients without dilated aortic roots since the survivors remain well, with excellent, maintained relief of outflow obstruction, without problems from haemolysis and thromboembolism, and without deteriorating autograft function or need for anticoagulants. Histology of five autografts examined up to seven years after operation has shown normal living architecture.

The use of biological valves for aortic valve replacement has been well established (Ross, 1962; Barratt-Boyes, 1964; Barratt-Boyes et al., 1969) and in many ways they have been shown to be superior to prosthetic valves particularly when long-term anticoagulant therapy is undesirable. The longest experience has been with the cadaveric aortic homograft but even with better techniques of sterilisation there have been occasional problems with degeneration and infection. An alternative and theoretically ideal valve replacement is the patient's own pulmonary valve (pulmonary autograft) (Ross, 1967). Indeed, of the few pulmonary autografts removed or retrieved at necoropsy, pathological examination has shown that the pulmonary autograft contains living cells and normal valvular architecture up to 7 years after the operation (L. Becu, personal observations). This suggests that this valve may retain the potential for good function for a longer period then other available valve substitutes. With 11 years of experience and improved techniques it is appropriate to report the late results of 85 patients who left hospital after aortic valve replacement with a pulmonary autograft.

'Present address: British American Hospital, Paseo Juan XXIII, No. 1, Madrid 3, Spain.

'Research Secretary initially supported by a one-year grant from the British Heart Foundation and subsequently by an anonymous donor.

Received for publication 8 March 1979

\section{Subjects and methods}

Between July 1967 and July 1972 (Fig. 1), 85 consecutive patients having had their aortic valve

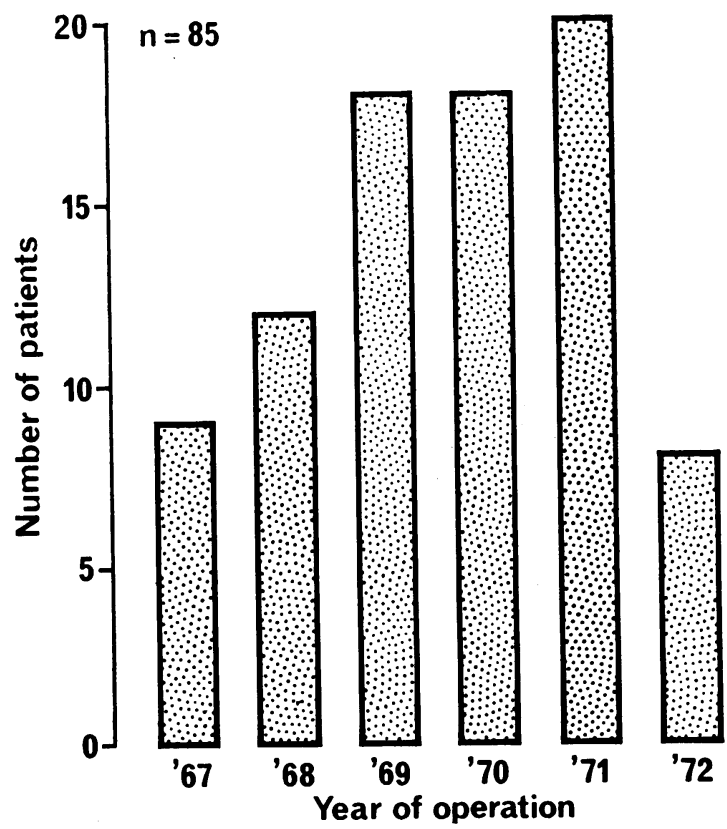

Fig. 1 Year of operation of 85 survivors of pulmonary autograft. 
replaced with their own pulmonary valve left the National Heart Hospital after one month and have been regularly assessed since. The surgical technique with cardiopulmonary bypass at normothermic temperatures consisted of excision of the patient's own normal pulmonary valve which was then used to replace the excised diseased aortic valve (Ross, 1967; Gonzalez-Lavin et al., 1970). A homograft was used to reconstruct the right outflow in 77 and autologous fascia lata in eight in 1968 and 1969.

The age of patients was 12 to 54 years (mean age 33 years), with 59 (69\%) below 40 years. Of the 85 patients, 26 had severe aortic regurgitation or mixed aortic valve disease with dilatation of the aortic root. This technique was not used in patients with Marfan's disease, dissection of the aorta, and other diseases causing unusual aortic root enlargement. No patient had active infective endocarditis at the time of operation.

Previous aortic valve surgery had been performed two to seven years earlier in 14. At the same time, 11 patients had other lesions corrected, such as closure of ventricular septal defect, subvalvar myotomy, and mitral valvotomy.

Clinical assessment, which was made every six months included physical examination, 12 lead electrocardiograms, routine penetrated posteroanterior and lateral chest radiographs for detection of graft calcification, and phonocardiography. Fifty-four $(63 \%)$ had cardiac catheterisation with measurement of gradients across the right and left ventricular outflows, aortography, and pulmonary arteriography when possible

\section{Results}

Five patients died in the first five years, and 80 have been followed for six to 11 years.

\section{LATE MORTALITY}

There have been $11(13 \%)$ late deaths (Tables 1A and $1 \mathrm{~B})$. In six (7\%) death was directly related to problems with either the autograft or the right sided reconstruction; in five there were other causes.

After five postoperative years, 78 of the original 85 were alive. Of 18 possible survivors, 14 were alive after eight years and no deaths have occurred after the eighth postoperative year.

\section{SEVERE AUTOGRAFT REGURGITATION}

(AORTIC REGURGITATION)

Important autograft regurgitation, as judged by the presence of a loud immediate diastolic murmur, widening of the pulse pressure above $50 \mathrm{mmHg}$ with a diastolic pressure lower than $70 \mathrm{mmHg}$ at rest, appeared during the first year in five (Fig. 2A and 7). One had been discharged with a clinically competent autograft two weeks after operation and

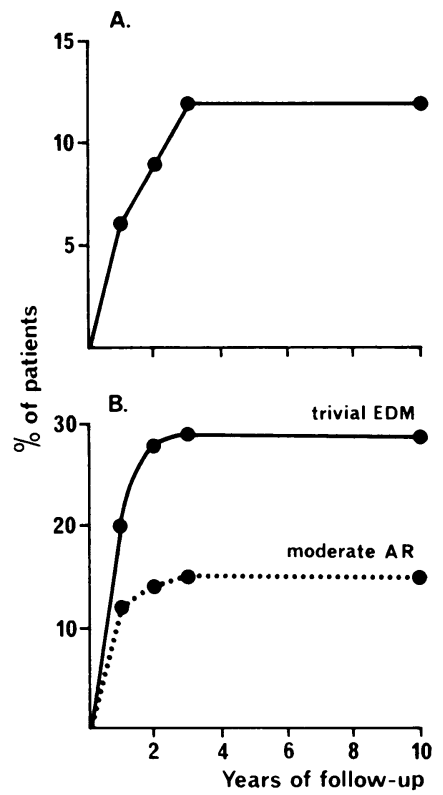

Fig. 2 (A) Incidence and time of appearance of important autograft (aortic) regurgitation in surviving patients after pulmonary autograft. (B) Incidence and time of appearance of early diastolic murmurs in those surviving patients who did not develop severe autograft regurgitation. For both graphs, on the vertical axis: percentage of surviving patients; on the horizontal axis: postoperative years.

Table 1A Cause of death in six patients in whom death was related to a problem with either the homograft or the autograft valve

\begin{tabular}{|c|c|c|c|c|}
\hline $\begin{array}{l}\text { Case } \\
\text { no. }\end{array}$ & $\begin{array}{l}\text { Age } \\
(y)\end{array}$ & Postop year & Cause of death & Findings at necropsy \\
\hline 1 & 15 & 1st $(2 / 12)$ & $\begin{array}{l}\text { Severe autograft } \\
\text { regurgitation }\end{array}$ & $\begin{array}{l}\text { Malposition of one } \\
\text { of autograft cusps }\end{array}$ \\
\hline 2 & 26 & 1st $(9 / 12)$ & $\begin{array}{l}\text { Pulmonary } \\
\text { embolism after } \\
\text { replacement of } \\
\text { infected homograft } \\
\text { (fungal) }\end{array}$ & No necropsy \\
\hline 3 & 34 & 1st $(10 / 12)$ & $\begin{array}{l}\text { Severe autograft } \\
\text { regurgitation }\end{array}$ & No necropsy \\
\hline 4 & 40 & 3rd & $\begin{array}{l}\text { Severe fascia lata } \\
\text { valve obstruction }\end{array}$ & No necropsy \\
\hline 5 & 49 & 6 th & $\begin{array}{l}\text { Early death after } \\
\text { reoperation for } \\
\text { mitral valve } \\
\text { disease, autograft } \\
\text { regurgitation, and } \\
\text { homograft } \\
\text { stenosis }\end{array}$ & $\begin{array}{l}\text { Autograft had a } \\
\text { perforated cusp; } \\
\text { homograft severely } \\
\text { calcified and } \\
\text { degenerated }\end{array}$ \\
\hline 6 & 32 & 7th & $\begin{array}{l}\text { During reoperation } \\
\text { for autograft root } \\
\text { sclerosis }\end{array}$ & No necropsy \\
\hline
\end{tabular}


Table 1B Cause of death in five patients in whom death was not related to either of the valves

\begin{tabular}{|c|c|c|c|c|}
\hline $\begin{array}{l}\text { Case } \\
\text { no. }\end{array}$ & $\begin{array}{l}\text { Age } \\
\text { (y) }\end{array}$ & Postop year & Cause of death & Findings at necropsy \\
\hline 1 & 41 & 4th & $\begin{array}{l}\text { Coronary heart } \\
\text { disease; previous } \\
\text { infarction + left } \\
\text { ventricular } \\
\text { aneurysm }\end{array}$ & No necropsy \\
\hline 2 & 54 & 6th & $\begin{array}{l}\text { Coronary heart } \\
\text { disease }\end{array}$ & No necropsy \\
\hline 3 & 33 & 6th & Sudden death & $\begin{array}{l}\text { Autograft and } \\
\text { homograft in } \\
\text { perfect condition }\end{array}$ \\
\hline 4 & 42 & 6th & $\begin{array}{l}\text { Myocardial } \\
\text { infarction }\end{array}$ & $\begin{array}{l}\text { Signs of very recent } \\
\text { subendocardial } \\
\text { infarction; } \\
\text { autograft and } \\
\text { homograft in } \\
\text { perfect condition }\end{array}$ \\
\hline 5 & 50 & 7th & Sudden death & $\begin{array}{l}\text { Autograft and } \\
\text { homograft in } \\
\text { perfect condition }\end{array}$ \\
\hline
\end{tabular}

returned a month later with acute severe aortic regurgitation, requiring immediate reoperation which showed that the cusps had torn away from the frame; this was the only frame mounted autograft in the series.

By the end of the third postoperative year, 10 $(12 \%)$ had important autograft regurgitation but the incidence has not increased since (Fig. 2A). Of these 10 patients, nine have required reoperation; in four the valve was repaired or repositioned and in five it was replaced. The remaining one with torrential regurgitation refused surgery and is alive nine years later leading a sedentary life.

\section{INCIDENCE OF DIASTOLIC MURMURS}

Excluding the 10 with serious autograft regurgitation, immediate diastolic murmurs were noted in 38 patients $(44 \%)$ in the first three postoperative years (Fig. 2B). In 13 (15\%) where there was some pulse alteration or aortic regurgitation was shown by angiography, the murmur was obviously caused by mild to moderate aortic regurgitation. In $25(29 \%)$, the faint murmur was not associated with other signs and it was uncertain clinically whether it was the result of pulmonary or aortic regurgitation unless investigation had designated the origin (Fig. 2B). In 27, these murmurs appeared in the first year, eight more developed murmurs in the second year, and the rest in the third (see Fig. 6). There has been no increase in the incidence of diastolic murmurs after the third year. All the patients in this group are asymptomatic and not requiring treatment.

PROBLEMS RELATED TO PULMONARY

VALVE REPLACEMENT

In the eight patients who had their right ventricular outflow tracts reconstructed with fascia lata the results were obviously unsatisfactory (Ross and Somerville, 1971) (Fig. 3). Of these patients, four

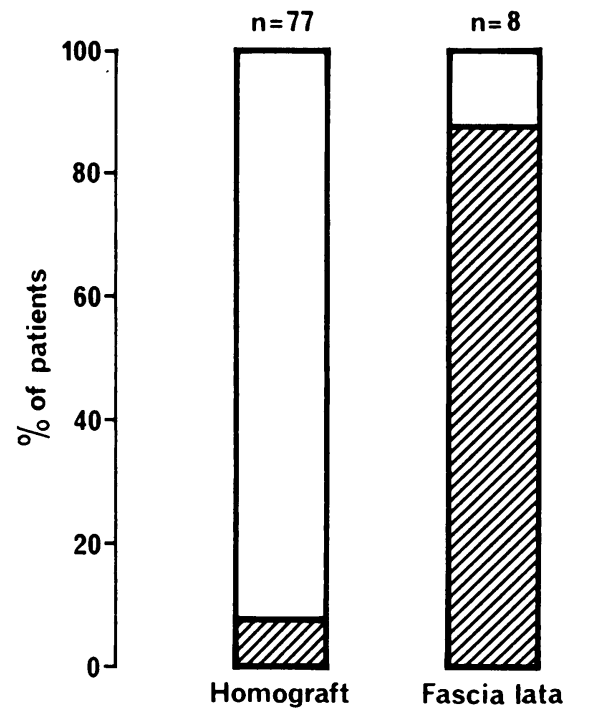

\section{no problems
stenosis and/or incompetenc?}

Fig. 3 Incidence of postoperative right-sided problems in relation to the right ventricular outflow tract reconstruction in 85 patients who had aortic valve replacement with a pulmonary autograft. There were a large number of problems with right-sided valves in the eight with fascial reconstruction.

have already had their valves replaced and one is awaiting reoperation for severe right outflow tract obstruction. Another patient had a pulmonary embolism after an episode of infective endocarditis and, since he had no autograft regurgitation and there was no systemic emboli during his illness, it was assumed that the infection took place on the already stenosed fascial valve. One patient died while awaiting surgery for significant stenosis and regurgitation of his valve. Only one patient with a fascial pulmonary valve is well and without any problems. In all patients reoperated on, the fascial cusps were completely fused and reduced to a thick narrow fibrous ring.

When aortic homografts have been inserted in the pulmonary position, sterilised by physicochemical methods up to 1969 and thereafter with antibiotic solutions (Longmore et al., 1966; Yacoub and Kittle, 1970; Lockey et al., 1972; Al-Janabi and Ross, 1973), the incidence of complications has been low (Fig. 3). Two had early problems requiring reoperation (Table 2); one developed fungal endocarditis and died during reoperation and the other was saved after the rupture of an infected right 
Table 2 Summary of reasons for reoperation, state of valves, and outcome of patients who required reoperation

\begin{tabular}{|c|c|c|c|c|c|c|c|}
\hline $\begin{array}{l}\text { Case } \\
\text { no. }\end{array}$ & $\begin{array}{l}\text { Postop } \\
\text { year }\end{array}$ & Reason & Surgery & $\begin{array}{l}\text { Autograft } \\
\text { state }\end{array}$ & $\begin{array}{l}\text { Right-sided } \\
\text { valve state }\end{array}$ & $\begin{array}{l}\text { Homograft } \\
\text { sterilising } \\
\text { method }\end{array}$ & Outcome \\
\hline $\begin{array}{l}1 \\
2 \\
3 \\
4 \\
5 \\
5 \\
6 \\
7 \\
8 \\
9\end{array}$ & $\begin{array}{l}\text { 1st } \\
\text { 1st } \\
\text { 1st } \\
\text { 2nd } \\
\text { 2nd } \\
\text { 3rd } \\
\text { 3rd } \\
\text { 5th } \\
\text { 6th }\end{array}$ & $\begin{array}{l}\text { Ac AR } \\
H \text { inf } \\
H \text { inf } \\
\text { AR } \\
\text { FL sten } \\
\text { AR (post inf end) } \\
\text { FL sten } \\
\text { AR, FL sten } \\
\text { MVD, AR, H sten }\end{array}$ & $\begin{array}{l}\text { A by Starr } \\
\text { H by } \mathbf{H} \\
\text { H by } \mathbf{H} \\
\text { A by FL } \\
\text { FL by } \mathbf{H} \\
\text { A by } \mathbf{H} \\
\text { FL by } H \\
\text { A by Björk, FL (Dacron) } \\
\text { M by Starr, A by Starr, } \\
\text { H by H }\end{array}$ & $\begin{array}{l}\text { Prol cusp } \\
\text { Prol cusp } \\
\text { Det cusp } \\
\text { Perf cusp }\end{array}$ & $\begin{array}{l}\text { Inf } \\
\text { Fungal } \\
\text { FL sten } \\
\text { FL sten } \\
\text { FL sten } \\
\text { Calc }\end{array}$ & $\begin{array}{l}\text { Eth Ox, irrad } \\
\text { FD }\end{array}$ & $\begin{array}{l}A \text { and } W \\
A \text { and } W \\
\text { Died early postop } \\
A \text { and } W \\
A \text { and } W \\
A \text { and } W \\
A \text { and } W \\
A \text { and } W \\
\text { Died early postop }\end{array}$ \\
\hline $\begin{array}{l}10 \\
11 \\
12 \\
13 \\
14 \\
15 \\
15 \\
16 \\
17\end{array}$ & $\begin{array}{l}\text { 6th } \\
\text { 7th } \\
\text { 7th } \\
\text { 7th } \\
\text { 8th } \\
9 \text { th } \\
\text { 10th } \\
10 \text { th }\end{array}$ & $\begin{array}{l}\text { FL sten, AR } \\
\text { AR, H sten } \\
\text { A root sclerosis } \\
\text { AR } \\
\text { MR, HR. AR } \\
\text { HR } \\
\text { HR + sten } \\
\text { AR, HR, MVD }\end{array}$ & $\begin{array}{l}\text { FL by } H, A \text { rep } \\
\text { A by Starr, } H \text { by } H \\
\text { A by Biörk } \\
\text { A rep } \\
M \text { by dura, } H \text { rep, A rep } \\
\text { H rep } \\
\text { H by xeno } \\
\text { A rep, } H \text { rep, } M \text { by Xeno }\end{array}$ & $\begin{array}{l}\text { Perf cusp } \\
\text { Prol cusp } \\
\text { Woody, inflamm } \\
\text { Prol cusp } \\
\text { Prol cusp }\end{array}$ & $\begin{array}{l}\text { Calc } \\
\text { Calc } \\
\text { Det cusp calc } \\
\text { Cusps } \\
\text { thickened }\end{array}$ & $\begin{array}{l}\text { Irrad FD } \\
\text { Eth ox FD } \\
\text { Irrad FD } \\
\text { Eth ox FD }\end{array}$ & $\begin{array}{l}A \text { and } W \\
A \text { and } W \\
\text { Died early postop } \\
A \text { and } W \\
A \text { and } W \\
A \text { and } W \\
A \text { and } W \\
\text { Still has imp AR }\end{array}$ \\
\hline
\end{tabular}

A, autograft; AB, antibiotic; Ac, acute; $A$ and $W$, alive and well; Calc, calcified; Det, detached; Dura, dura mater valve; End endocarditis; Eth ox, ethylene oxide; FD, freeze dried; FL, fascia lata valve; Fr, fresh; H, homograft; Imp, important; Inf, infected; Inflamm, inflammatory; Irrad, irradiated; M, mitral valve; MVD, mitral valve disease; Perf, perforated; Postop, postoperatively; Prol, prolapsed; R, regurgitation; Rep, repaired; Rupt, ruptured; Sten, stenosis; Xeno, xenograft.

ventricular aneurysm at the proximal end of the graft. He has survived 10 years, well, without autograft regurgitation and living a normal life in one of Her Majesty's prisons where he is confined for robbery with violence.

A further six patients required reoperation for homograft dysfunction. Calcification and rigidity of the cusps was found in five and one cusp was detached from the calcified wall in one. Three of these homografts were replaced and three were able to be repaired using a unicusp homograft. They had been sterilised by ethylene oxide and freeze dried in three, irradiation and freeze dried in two, and by the combination of both methods in the remaining one.

Calcification of the right sided homografts was radiologically detected in 22 patients $(28 \%)$ but it was not evident before the second postoperative year (Saravalli et al., 1979) and not associated with haemodynamic problems in 16.

\section{REOPERATIONS}

Seventeen patients have had reoperation one to 10 years after the original surgery (Table 2). Seven $(41 \%)$ were reoperated on in the first three years and 10 in the remaining years of follow-up. Five patients were reoperated on for isolated autograft regurgitation, six for problems related to the pulmonary valve replacement, and a further six for the combination of right and left sided problems (Table 2). The original autograft has had to be removed in seven patients, of whom five are still surviving with another valve (see Fig. 6). In most of these cases, the histological study of the autograft has persistently showed a striking conservation of the valvular tissue up to seven years after implantation. Elastic layers were shown to be preserved and normally arranged and large amounts of living cells were present among them (Fig. 4). There has been no sign of calcification or endocardial or medial thickening. This remarkable histology was also found when autografts from necrospy specimens could be examined. The only exception to this has been one case in which a woody inflammatory process had taken place in the autograft root, involving its cusps, in a patient who had infective endocarditis three months after the original operation.

\section{REINVESTIGATION}

There has been no established policy regarding reinvestigation in view of the difficulties of getting patients from long distances back into hospital. However, $54(63 \%)$ out of the 85 reported patients have had haemodynamic studies three weeks to eight years after operation. Twenty-nine were catheterised during the first postoperative year, 22 as a routine test to assess surgical results, and seven because of the appearance of complications or evaluation of residual lesions. Thirteen patients had a second postoperative catheterisation eight months to eight years after the first one. This was performed in 12 cases because of changes in the clinical state.

All investigations included measurement of gradients across the right and left ventricular outflow, right and left ventricular angiography, aortography, and pulmonary artery arteriography.

In no case was a pulmonary autograft gradient 


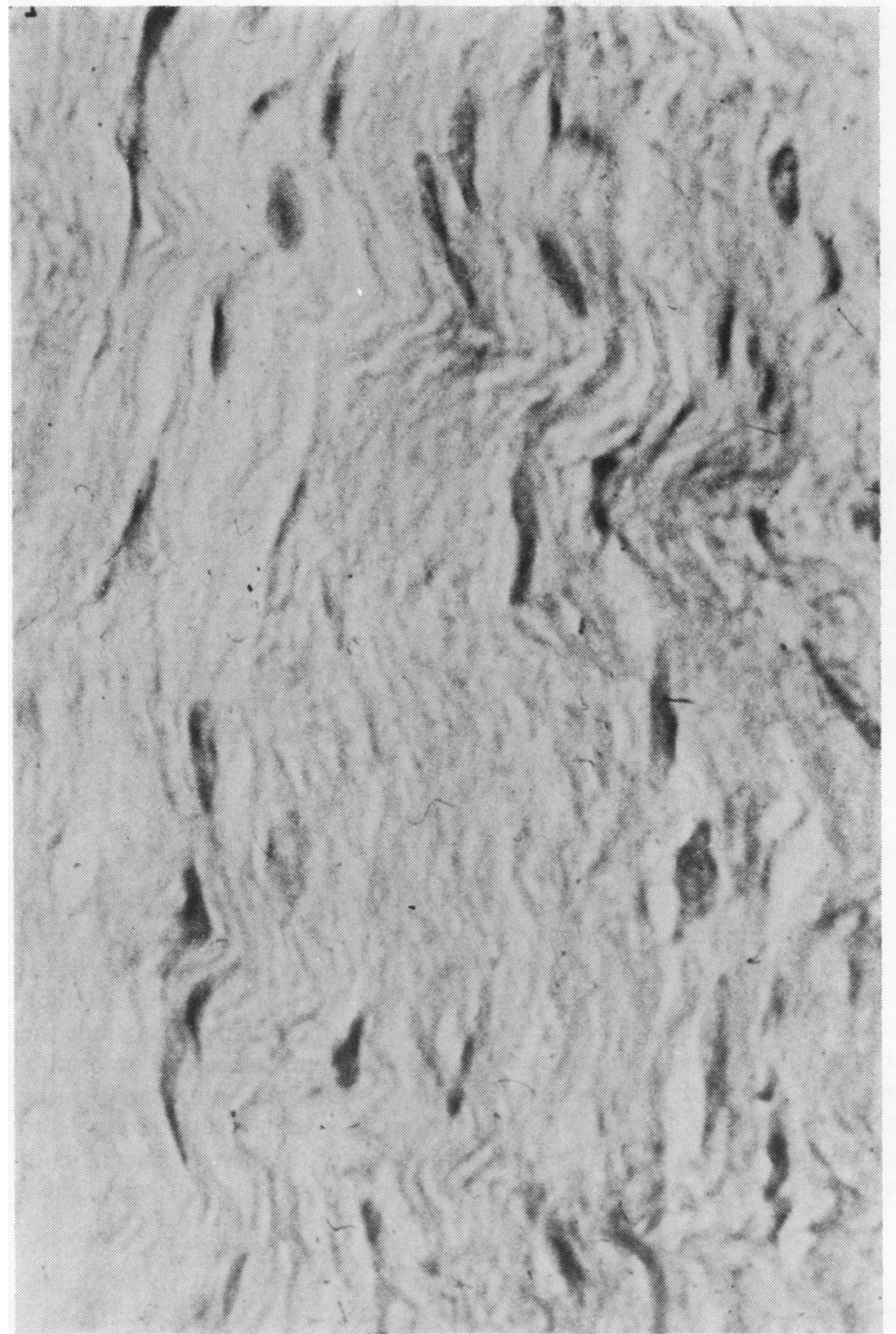

higher than $12 \mathrm{mmHg}$ found. A trivial degree of autograft regurgitation was assessed in 35 asymptomatic patients. However, the degree of regurgitation found at the first investigation had not increased in the 13 patients who underwent a second study. In all patients who have not shown signs of important regurgitation because of graft malposition, routine aortography showed normal looking aortic root with normal opening and closing of pliable autograft cusps.

Fascia lata valves used for right sided reconstruction have always shown important gradients at reinvestigation whereas gradients of only up to $23 \mathrm{mmHg}$ have been recorded across the right sided homografts at first postoperative catheterisation. These gradients increased significantly at the second investigation in eight patients, six of whom have already had homograft replacement or repair for homograft calcification and obstruction (Table 2). A properly functioning homograft is shown (Fig. 5).

\section{OTHER PROBLEMS}

Seven patients have had the certain clinical diagnosis of infective endocarditis one month to seven years after surgery. In two cases this produced serious autograft regurgitation which led to autograft replacement while in one case a woody inflammatory
Fig. 4 Masson's trichrome stain (original magnification $\times 40$ ). years after operation. There are a large number of living cells among the orderly arrangement of $a$ a sparse but well-formed background of elastin. 


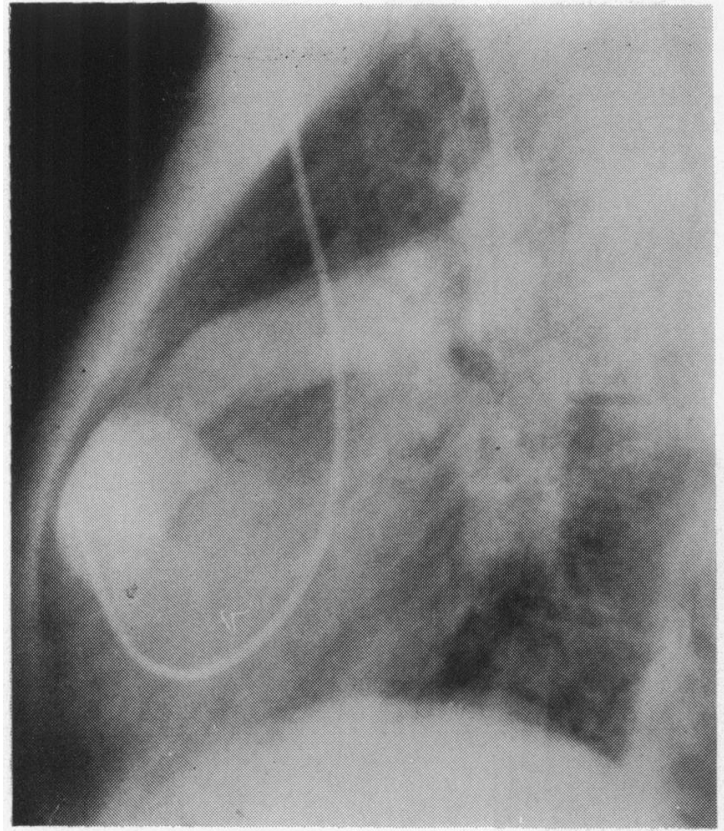

Fig. 5 Lateral view of right ventricular angiogram from a patient who had pulmonary autograft and homograft replacement of the pulmonary valve six years before. Cusps and outflow appear normal without any systolic gradient.

process involving the whole aortic root with subsequent involvement of the autograft cusps developed, causing severe regurgitation which also necessitated reoperation. In the remaining four cases, after treatment of the illness, significant clinical changes did not appear. Of these seven patients, two had already had infective endocarditis before surgery.

One patient has been living for seven years with a pacemaker because of complete heart block dating from the time of surgery and three others are neurologically handicapped after perioperative complications; these problems were seen only among the first 12 patients in the series.

Two patients have required operation for peripheral vascular disease and a further two have developed important mitral valve disease and await reoperation for this. Five patients developed systemic hypertension which has been controlled by medical therapy and has not been the cause of increasing autograft regurgitation or deterioration.

\section{GENERAL CLINICAL STATE}

Sixty-nine surviving patients are living with the same original autograft six to 11 years after operation while five others are surviving with another valve in the aortic position. Fifty-six patients are asymptomatic, physically and mentally, and are able to do full time jobs. Twelve of these patients are doing strenuous work, five others regularly play sport, and a further two are attending college. There have also been six successful pregnancies and deliveries in four female patients, three to six years after operation.

\section{Discussion}

A superficial look at the late results of pulmonary autograft may suggest to the unwary critic that perhaps there are too many problems with this complex operation for aortic valve replacement. However, this series includes all patients since the technique was introduced and so the early mortality and some of the late results are influenced by the errors of pioneering. Thus, it is unreasonable to compare the late results of the first 50 survivors of this procedure with some other form of aortic valve

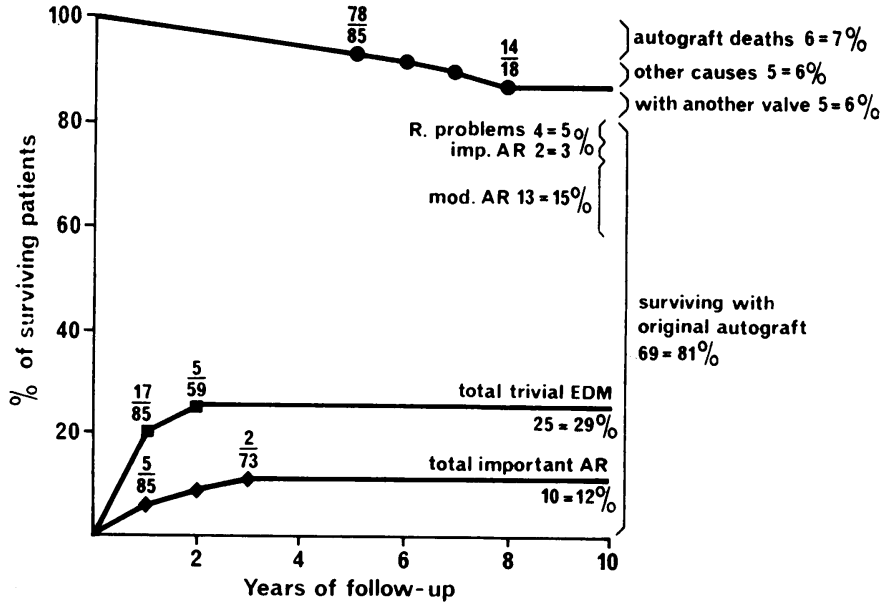

Fig. 6 Summary of current state and problems in 85 patients who left hospital after pulmonary autograft. Lower numbers relate to actual total of patients who had survived that length of time and upper numbers relate to those with the complication. 
replacement with the 'trial and error' excluded. Unquestionably the learning period of surgical technique included errors which can now be avoided since the related problems are no longer seen in the recent series. For instance, in the first 20 patients, no coronary perfusion or real myocardial protection was used, sometimes leading to fatal circumferential subendocardial infarction; furthermore in the survivors of this period, there may well have been myocardial damage and scars to account for repetitive ventricular tachycardia in three fatal cases. In all three the autograft valves were perfect and living. Furthermore, operative damage to conducting tissue with production of right bundlebranch block (four) and complete heart block in two occurred early on and obviously contributed to some morbidity.

To evaluate a valve used for replacement of a diseased valve, attention must be primarily directed to the function and degeneration of that valve. With regard to the autograft, a few important facts emerge. Cusp rupture has occurred only once in an 11-year period in the only frame mounted autograft used for technical reasons in a boy who already had two previous aortic valve operations. Important aortic regurgitation occurred early and did not develop in any after the first three years. In those with this problem who were reoperated or who died the aortic regurgitation has always been the result of malposition of one cusp which obviously causes important regurgitation in a manner which predisposes to progression. This is a technical problem related to positioning and tailoring of the root. It occurred mostly in patients with preoperative dominant or lone aortic regurgitation $(60 \%)$ so that the technique is rarely used in such patients with pronounced dilatation of the aortic root which cannot readily or safely be reduced. The microscopical features of the autograft show normal histology with aligned living cells looking like those of a normal valve. No calification or dead tissue has been found in any. Indeed, one of the major theoretical and practical attractions is that it remains living and generally free of disease. One exception to this is a 23-year-old woman with rheumatic valves who had a serious febrile illness three months after autograft replacement of her regurgitant aortic valve. Aortic regurgitation progressed and seven years later the valve was replaced. Whether the woody inflammatory tissue in the root and the base of the cusps was an autoimmune process or a chronic valvulitis we do not know. The purpose of mentioning this exception is to document it so that others may find a solution.

The relatively high incidence of immediate diastolic murmurs with little or no haemodynamic change has not been a cause for concern. They appeared only in the first three years without progression or increasing incidence thereafter. We suspect that the majority are a result of trivial aortic regurgitation. In some where aortography has confirmed a competent aortic valve, the murmurs clearly originated from the right side. The critics of this procedure understandably comment on this high incidence of trivial murmurs but this is not a reason for alarm since the haemodynamic lesion appears to be static in the first decade, there is no reason to attribute it to tissue degeneration, and the long-term prognosis of trivial rheumatic or congenital aortic regurgitation is excellent. Indeed, the prognosis of autograft regurgitation may be even better since the valve seems not to be prone to calcification, thickening, or rupture. The incidence of late infective endocarditis on the autograft is only 6 per cent, less than in homografts or mechanical valves, but shows that these patients must be protected for life.

The real problem which worries us still is the replacement for the removed pulmonary valve. It is irrelevant to the main theme to discuss the now known disaster of using fascia lata (Ross and Somerville, 1971). This unquestionably added to the late incidence of reoperation and often precipitated reinspection or surgery on the autograft. When surveying the problems of the well-tried homograft in the right ventricular outflow tract there was an acceptable low early morbidity (2\%) from infection, clearly related to methods of sterilisation which are common to the use of homografts in any site, varying from centre to centre and remaining partly unsolved. However, six patients $(7 \%)$ after the sixth postoperative year required removal of the right-sided homograft valve for progressive symptomatic obstruction and/or regurgitation. Strangely, this has not been the experience using the same homografts for repair in congenital cyanotic heart disease (Somerville, 1975) where the graft-bearing wall calcifies earlier and more intensely (Saravalli et al., 1979).

Three of the six valves had been irradiated before surgery which may have led to the degenerative problems. However, in one, not irradiated, we have no obvious explanation for dysfunction. Whether it relates to the unknown details of the age and sex of the donor or to technical problems of malpositioning the graft cannot be stated. Unquestionably the details of the donor of the homograft must be documented as they may influence the fate of homograft valves in all sites.

The clinical state reflects accurately the function of the homograft 'pulmonary' valve and the autograft aortic valve. There were no surprises and with 
the exception of the above-mentioned problem there was no progressive change in serial studies. The autograft aortic valve invariably looks surprisingly normal and relief of left outflow obstruction is satisfactory, resting gradients being 0-12 mmHg.

It is accepted that this is a technically more difficult, demanding, and time-consuming operation than others used for aortic valve replacement and as such must carry a higher initial mortality. However dexterous the surgeon, the procedure may not be possible in many centres because of lack of homografts, funds, or excess numbers of patients.

In eight young patients referred specifically for pulmonary autograft, it could not be undertaken because of minor congenital abnormalities in the pulmonary valve.

In favour of the procedure is that we have shown that the normal pulmonary valve can function normally for a decade and in those few examined histologically, it retains the features of 'living' tissue. The technical problems are mainly solved and we believe from our studies that this is the operation of choice in young patients with good left ventricular function, a normal pulmonary valve, and no aortic root dilatation or autoimmune disease.

\section{References}

Al-Janabi, N., and Ross, D. N. (1973). Enhanced viability of fresh aortic homografts stored in nutrient medium. Cardiovascular Research, 7, 817-822.

Barratt-Boyes, B. G. (1964). Homograft aortic valve replacement in aortic incompetence and stenosis. Thorax, 19, 131-150.

Barratt-Boyes, B. G., Roche, A., Brandt, P., Smith, J., and Lowe, J. (1969). Aortic homograft valve replacement. A long term follow up of an initial series of 101 patients. Circulation, 40, 763-775.

Gonzalez-Lavin, L., Geens, M., Somerville, J., and Ross, D. N. (1970). Autologous pulmonary valve replacement of the diseased aortic valve. Circulation, 42, 781-785.

Lockey, E., Al-Janabi, N., Gonzalez-Lavin, L., and Ross, D. N. (1972). A method of sterilization and preserving fresh allograft heart valves. Thorax, 27, 398-400.

Longmore, D. B., Lockey, R., Ross, D. N., and Pickering, R. V. (1966). The preparation of aortic valve homografts. Lancet, 2, 463-464.

Ross, D. N. (1962). Homograft replacement of the aortic valve. Lancet, $2,487$.

Ross, D. N. (1967). Replacement of the aortic and mitral valves with a pulmonary autograft. Lancet, 2, 956-958.

Ross, D. N., and Somerville, J. (1971). Fascia lata reconstruction of the right ventricular outflow tract. Lancet, 1, 941-943.

Saravalli, O., Somerville, J., and Jefferson, K. (1979). Calcification in aortic homografts used for reconstruction of the outflow tract of the right ventricle. Fournal of Thoracic and Cardiovascular Surgery (in press).

Somerville, J. (1975). Homograft reconstruction of the right ventricular outflow tract in pulmonary atresia and extreme tetralogy of Fallot-Late results. In Second Henry Ford Hospital International Symposium on Cardiac Surgery, p. 349, ed Julio C. Davila. Appleton Century Crofts, New York.

Yacoub, M., and Kittle, C. F. (1970). Sterilization of valve homografts by antibiotic solution. Circulation, 41 and 42, Suppl. 11, 29-32.

Requests for reprints to Dr Jane Somerville, National Heart Hospital, Westmoreland Street, London W1M 8BA. 